УДК 371.315

DOI https://doi.org/10.24919/2308-4863/34-4-42

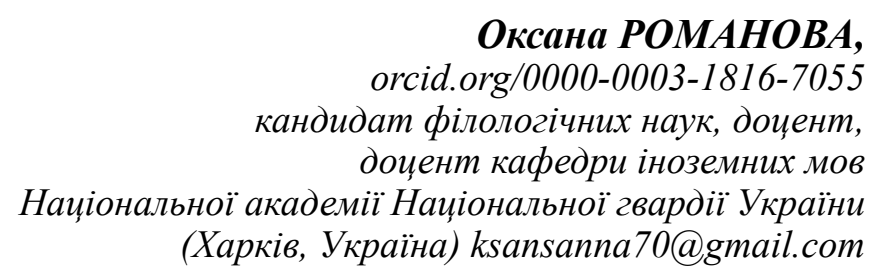

олена МУДРИк,

orcid.org/0000-0001-9834-4212

стариий викладач кафедри іноземних мов

Національної академії Національної гвардії України

(Харків, Україна) тиdrik.elena@gmail.com

\title{
ПСИХОЛОГО-ПЕДАГОГІЧНІ ПРИНЦИПИ СТВОРЕННЯ МОТИВАЦІЙНОГО СЕРЕДОВИЩА В ДИСТАНЦІЙНИХ КУРСАХ
}

У статті визначено показники очінки якості впровадження та застосування дистанційного навчання. Сформовано основні заходи щцодо впровадження дистанційної освіти у ЗВО. Виділено негативні сторони, підходи вирішення проблем, а також перспективи дистаниійної форми навчання; ключові мотиваційні аспекти, які впливають на ефективність роботи з дистаниійними курсами (на базі системи керування навчанням Моодlе).

Щоб вирішити проблему якості освітніх послуг, які отримують студенти дистанційної форми навчання, викладачі повинні розвивати і впроваджувати інформаційні технологї̈, які сприяють розвитку дистанційної освіти. Дистаниійне навчання в університеті дає студентам можливість ціілодобового доступу до навчальних матеріалів, постійну підтримку й консультаиії викладачів і методистів, оп-liпе відеолекиїі, віртуальні тренажери та інші технологічні рішення для забезпечення ефективного процесу навчання. Використання мережі Internet надає оперативний доступ до інформаційних ресурсів навчального закладу та можливість ефективної взаємодії «викладач-студент» як в оп-line, так і в оff-line режимах.

Мотивачія - необхіднии складник навчання, який повинен підтримуватися протягом усього процесу навчання. Використання комп'ютера не завжди може гарантувати активність студентів. У них потрібно підтримувати мотивацію та зацікавленість матеріалом. На мотиваційному етапі студенти повинні усвідомити, для чого їм потрібно вивчити певний розділ дисципліни, щэо саме вони повинні засвоїти, щэоб успішно виконати основну навчальну задачу.

Мотиваційний етап здебільшого складається зі створення навчально-проблемної ситуації, яка вводить студентів у предмет вивчення теми. Навчально-проблемна ситуація може бути сформована викладачем різними прийомами: 1) постановкою завдання перед студентами, вирішення якого можливе лише на основі вивчення цієї теми; 2) бесідою (розповіддю) викладача про теоретичну та практичну значущість майбутньої теми (розділу); 3) розповіддю викладача про те, як вирімувалася проблема в історії науки.

Ключові слова: психологія життєвої успішності, мотиваційні аспекти психотехнологій у дистанційних курсах розвитку, дистанційне навчання, дистанційна освіта, проблеми дистанційного навчання, перспективи дистанційного навчання, проблеми дистанційної освіти, перспективи дистанційної освіти. 


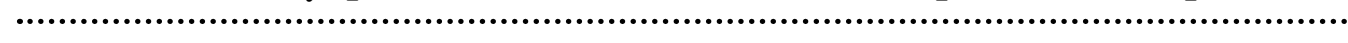

\begin{abstract}
Oksana ROMANOVA,
orcid.org/0000-0003-1816-7055

Candidate of Philological Sciences, Associate Professor, Associate Professor at the Department of Foreign Languages

National Academy of the National Guard of Ukraine (Kharkiv, Ukraine) ksansanna70@gmail.com
\end{abstract}

Olena MUDRYK, orcid.org/0000-0001-9834-4212

Senior Instructor at the Department of Foreign Languages National Academy of the National Guard of Ukraine (Kharkiv,Ukraine) mudrik.elena@gmail.com

\section{PSYCHOLOGICAL AND PEDAGOGICAL PRINCIPLES OF CREATING A MOTIVATIONAL ENVIRONMENT IN DISTANCE LEARNING COURSES}

The article identifies indicators for assessing the quality of introduction and implementation of distance learning. Priority activities for the introduction of distance education in higher education institutions have been formed. Negative aspects, problem-solving approaches and distance learning perspectives, the key motivational aspects that affect the efficiency of working with distance courses (based on the Moodle learning management system) are highlighted.

Teachers must develop and implement information technologies that promote the development of distance education in order to solve the problem of the quality of educational services that students receive when distance learning. Distance education at the university provides students with 24-hour access to teaching materials, teachers and methodologists' constant support and consultations, on-line video lectures, virtual simulators and other technological solutions to ensure an efficient learning process.

The use of the Internet gives the opportunity of prompt access to information resources of the educational institution and allows effective interaction "teacher-student" both in on-line and off-line modes. Motivation is the necessary component of teaching-learning process that must be supported throughout the entire teaching-learning process. Using a computer can not always guarantee student activity. Students need to be motivated and involved. At the motivational stage, students must understand why and what for they need to study the section of the discipline, what they need to learn to complete the basic task successfully.

The motivational stage usually consists of creating a problem-solving situation that introduces students to the subject of study. Learning-problem situation can be designed by the teacher in different ways: 1) setting a task for students, the solution of which can only be achieved by studying the topic; 2) conversation (teacher's short story) on the theoretical and practical significance of the topic (section); 3) teacher's short story about how the problem was solved in the history of science.

Key words: psychology of success, motivational aspects of psychotechnologies in distance development courses, distance learning, distance education, problems of distance learning, prospects of distance learning, problems of distance education, prospects of distance education.

Постановка проблеми. Про якість освіти нині говорять дуже багато. Якщо кілька років потому ці обговорення стосувалися традиційної освіти, то нині поняття якості освіти застосовується щодо дистанційного навчання. Тенденції впровадження сучасних інформаційних технологій у процес навчання найбільш розвинених країн показують, що відбувається процес кардинальних змін в системі освіти, переоснащення навчальних закладів відповідно до сучасних вимог якості навчання (Адлер, 1997). Завдання, які необхідно виконати викладачам і працівниками 3ВО, - це впровадження системи дистанційної освіти та забезпечення сприятливого впливу нових технологій на освітній процес.

Аналіз досліджень. Дослідники В. Биков, Д. Богоявленська, А. Іванніков, Н. Клокар зазначають про різноманіття принципів побудови, організації та реалізації дистанційного навчання; основні вимоги до дистанційної освіти висвітлено науковцями М. Карпенком, С. Рибалко, А. Хуторской. Соціально-психологічні аспекти дистанційної освіти аналізує А. Мінаков; О. Малінко досліджує іiі організаційну структуру та психолого-педагогічні основи; С. Сисоєва працювала над висвітленням психолого-педагогічних проблем дистанційного навчання.

Хотілося б зупинитися на аналізі окремих психологічних особливостей дистанційної освіти, іiі позитивних і негативних впливів на особистість студента та ефективності навчального процесу загалом.

Мета статті - розкрити зміст поняття «мотивація», визначити переваги і недоліки при застосуванні дистанційної форми навчання у ЗВО, ключові мотиваційні аспекти, які впливають 
на ефективність роботи 3 дистанційним курсом; виділити психолого-педагогічні принципи створення мотиваційного середовища в курсах розвитку 3 тренінгового до дистанційного формату зі збереженням інтерактивності, мотиваційного впливу і суб'єкт-суб'єктної взаємодії.

Виклад основного матеріалу. Дистанційна освіта з'явилася не так давно поряд із вже зарекомендованими традиційними формами навчання (очною, заочною). Ця форма навчання є найбільш прийнятною 3 точки зору економії як фінансового, так і часового ресурсу. Порівняно з іншими формами освіти дистанційне навчання здатне задовольняти потреби широкого кола споживачів освітніх послуг.

Електронне навчання розпочалося приблизно одночасно в Свропі і Північній Америці. Цьому сприяло швидке поширення комп'ютерних та інформаційно-комунікаційних технологій, а також глобалізація розвитку освіти не тільки в Свропі і Північній Америці, а й в усьому світі.

Головним фактором, який визначає специфіку психолого-педагогічних умов дистанційного навчання через мережу Internet, $\epsilon$ відсутність «живого» спілкування. Міжособистісне спілкування за допомогою телекомунікацій здебільшого забезпечує функціонально повноцінну схему здійснення навчального процесу, включаючи прямий і зворотній зв'язок між студентом і викладачем. Однак функції останнього надзвичайно обмежені, оскільки викладач не $\epsilon$ головним і безпосереднім джерелом навчальної інформації. Тому основна методична проблема навчання іноземних мов фактично зводиться до того, як забезпечити досягнення поставлених навчальних цілей при обмежених можливостях викладача керувати навчальним процесом.

У світі існують різні тлумачення поняття «модель дистанційного навчання», які мають як спільні, так і специфічні риси. Специфіка зумовлена насамперед соціально-економічними і соціально-культурними особливостями національних освітніх систем. Кожна країна визначає власні шляхи створення і розвитку національної системи дистанційного навчання.

Світ рухається в бік розвитку віртуального товариства, про цю тенденцію вже написано безліч праць. $\mathcal{C}$ прибічники «віртуалізації» суспільства, $€$ іiї опоненти, але безперечними $є$ зміни, які відбуваються в комунікаціях, освіті, суспільстві. На це впливають різні фактори:

1. Зворотний зв'язок.

2. Особистісний фактор.

3. Групова динаміка, вплив групи.
Ці фактори є важливими агентами впливу, тому актуальним $є$ завдання збереження цих аспектів у разі трансформації тренінгової програми в дистанційний формат. Дуже важливо зберегти базові засади, принципи роботи і створити мотивуючий простір у нашому дистанційному курсі при перекладі чи певній трансформації технологій до дистанційного формату психологічної роботи 3 дорослими. Виділяємо такі найважливіші блоки:

Мотивачійний блок: активність, самостійність у прийнятті рішень, мотивація для досягнення, пізнання нового чи використання звичного контексту.

Блок стереотипів: я можу / не можу, можу тільки сам / можу разом 3 іншими, очікую невдачі / очікую успіхів, навколишнє середовище позитивне / негативне, я позитивний / негативний, я для себе / я для інших, усе мені дається легко / все дається важко, на зміни треба багато часу / мало часу.

Блок самообмежень: заборона собі бути кращим, заборона бути лідером, заборона бути «для себе», заборона бути автономним, заборона бути гнучким, заборона отримувати подарунки (в широкому смислі слова - шанси від життя).

Можна оцінювати якість впровадження та застосування дистанційної освіти за допомогою таких показників:

- результативність (ступінь засвоюваності знань, можливість застосовувати накопичені знання на практиці, успішність, індивідуальний процес навчання, гнучкі консультації);

- доступність усім верствам населення (студенти, бізнесмени, інваліди, військовослужбовці, ув'язнені);

- ресурсомісткість (відсутність необхідності відвідувати лекції і семінари, фінансові витрати, матеріальні ресурси, аудиторії, викладачі);

- оперативність (час на засвоєння знань, донесення їх до студентів);

- комплексне програмне забезпечення;

- демократичний зв'язок «викладач - студент»;

- провідні освітні технології.

Те, що ми назвали, можна віднести до показників ефективності процесу дистанційного навчання. Дистанційна освіта розвивається дуже швидко, і для України вона $є$ перспективною формою вищої освіти. На нашу думку та за нашими спостереженнями, для створення мотиваційного середовища у дистанційних курсах потрібні такі ключові мотиваційні аспекти, які впливають на ефективність роботи з дистанційними курсами:

1. Ділова мотивація, яка $є$ складником професійної діяльності (характерна для 90\% респондентів). Цей мотив спрямований на досягнення 
певної мети: пошуку необхідної інформації і взаємодії з окремою людиною тощо.

2. Пізнавальна мотивація (80\%). Вона надає нові знання студентам, візуальні й слухові образи. Це нові сервісні можливості, гіпертекстова інформація, люди, ідеї, концепції.

3. Мотивація співробітництва (61\%). Діяльність людини є соціальною за змістом і структурою. Взаємодіючи, суб' єкти обмінюються результатами, разом розв'язують проблеми.

4. Мотивація самореалізації (50\%). Інтернет розглядається як засіб вияву й розвитку власних інтелектуальних і творчих можливостей. Єдиний комплекс соціальних мотивів, до складу якого входять мотиви, пов'язані з різними аспектами ділового й міжособистісного спілкування. Серед них мотиви співробітництва, афіліації, самореалізації, самоутвердження та комунікативний мотив. Вважається, що робота в інтернеті - це гра та імпровізація, до того ж вона сприяє розвитку особистості й життєвому успіху, супроводжується відчуттям включення в глобальний інформаційний простір.

5. Рекреаційний мотив (лат. "Recreatio" - «відновлення»; «призначений для користування під час відпочинку, відновлення сил»). Основна сфера зацікавлень респондентів цієї групи (40\%) - телеконференції за темами, хобі та гумор, а також нетематичні телеконференції. Поряд із мотивами рекреації суб'єктів дослідження спостерігаються мотивисамореалізації,афіліації,самоствердження, а також пізнавальний і комунікативний мотиви.

6. Мотивація афіліації (англ. "Affiliation" «поєднання, зв'язок»; «емоційна потреба в спілкуванні, контактах, дружбі, взаєморозумінні, любові, яка виявляється через прагнення бути в соціумі, контактувати з іншими індивідами, взаємодіяти з ними, надавати їм допомогу»). Прагнення користувачів (40\%) знайти в інтернеті референтну групу, зайняти своє місце в ній.

7. Мотивація самоствердження (30\%). Самоствердження $\epsilon$ необхідним аспектом активності «Я», що реалізує сутнісні властивості людської особистості. Залежно від типу особистості, індивідуальних особливостей і соціальної ситуації самоствердження набуває різних форм. Воно може реалізуватися шляхом наукової або художньої творчості, комунікативної активності, шляхом побудови соціальної кар'єри, прагнення до лідерства, саморозвитку особистості. Оскільки інтернет надає нові комунікативні й пізнавальні можливості, то можна припустити, що досліджуваний тип самоствердження пов'язаний із різними феноменами спілкування (пошуком референтної групи, ідентифікацією з іiі цінностями й спромож- ністю самовираження в ній). Респонденти цієї групи цікавляться телеконференціями для вільного обговорення.

8. Комунікативна мотивація (лат. "Communicative" - «спілкуюсь із кимось»; «виробництво, передача та споживання значень через різні засоби: усні, друковані, радіо, фільми, комп'ютерні мережі у безлічі контекстів: міжособистісних, расових, культурних, політичних, організаційних, міжнародних»). Респонденти цієї групи (25\%) стверджують, що інтернет дає змогу переборювати комунікативний дефіцит, який виникає у повсякденному житті. Мотив комунікації сполучається 3 усім блоком мотивів соціально-комунікативного характеру, а також із рекреаційним мотивом. Оцінюючи особисті наслідки роботи в інтернеті, респонденти з комунікативною мотивацією зазначають, що він сприяє розвитку особистості, глобалізує ії інформаційну діяльність.

Варто виділити і негативні сторони, з якими можна зіткнутися у процесі впровадження дистанційної освіти в освітній процес:

1. Занадто слабка координуюча функція з боку Міносвіти (неузгодженість у нормативно-правовому забезпеченні, у стандартизації, в економічних і фінансових питаннях, в оцінках якості освіти).

2. Конкурентна боротьба серед закладів вищої освіти за студентів як основне джерело фінансування, яка призвела до автономізації багатьох 3ВО.

3. Людський фактор відіграє важливу роль у процесі навчання, тому що викладач при безпосередньому контакті зі студентом може передавати і прищеплювати певні навички, а при дистанційній освіті він повністю зникає.

4. Методи навчання, які існували до цього, погано поєднуються 3 новими технологіями, а більшість методичних і навчальних матеріалів не підходять для дистанційного навчання.

5. Дистанційно навчатися не можливо за деякими спеціальностями, оскільки певні дисципліни припускають наявність складних лабораторних практикумів, які проводяться під контролем викладача.

6. Відсутність навичок роботи 3 інформаційними технологіями у багатьох викладачів. У зв'язку з цим виникають труднощі 3 підготовкою навчального матеріалу, який підходить для використання при дистанційній освіті.

7. Опір професорсько-викладацького складу впровадженню сучасних технологій.

8. Витрати на навчання викладачів сучасним інформаційним технологіям, фінансові витрати ЗВО на придбання необхідного технічного оснащення. 
9. Необхідність стандартизації вимог до наданих навчальних матеріалів, необхідних при дистанційному навчанні.

10. У технічному плані - слабкі канали зв'язку, висока вартість Internet.

11. Створення інформаційно-освітнього середовища, особливо в частині наповнення бази даних електронними підручниками та навчально-методичними матеріалами.

12. Збільшення пропускної здатності телекомунікаційного каналу, розвиток корпоративної мережі 3ВО і філій до рівня, який забезпечує організацію навчального процесу за всіма видами навчальної діяльності та технологіями педагогічного спілкування.

Найбільш актуальними проблемами, які виникають при впровадженні дистанційної форми навчання у ЗВО, $є$ :

- контроль за наявністю знань у студентів;

- проблема оцінки якостінаданих освітніх послуг;

- проблематичність об’єктивної оцінки знань студентів.

Немає повної гарантії, що студент навчається самостійно, виконує ті чи інші завдання, необхідні длязасвоєння дисципліни,щопідтверджують наявність знань. Частковим вирішенням цієї проблеми $\epsilon$ контроль у режимі on-line або використання технологій змішаного навчання (Москаль, 2008). Так, можна знайти деякі підходи щодо вирішення проблем впровадження дистанційної освіти у ЗВО:

- розроблення концепції дистанційної освіти;

- розвиток і адаптація корпоративної мережі 3ВО, доведення пропускної здатності телекомунікаційного каналу (вихід в Internet) до мінімально необхідної, яка відповідає вимогам забезпечення навчального процесу дистанційної освіти;

- консолідація зусиль організаторів і розробників;

- створення єдиної корпоративної системи дистанційної освіти і єдиних ресурсів;

- організація підготовки та підвищення кваліфікації викладачів і технічного персоналу в галузі методології та інформаційних технологій дистанційної освіти;
- створення електронної бібліотеки, включення ii у корпоративну мережу бібліотек регіону, забезпечення доступу до відкритих бібліотек мережі Internet;

- створення центру дистанційної освіти на базі ЗВО України, вступ до Міжнародної асоціації відкритих електронних бібліотек, інших відповідних організацій.

Висновки. Підсумовуючи зазначене вище, можна констатувати, що ми презентували огляд нашого підходу до проблеми «перекладу» технологій тренінгового формату в дистанційний без втрати або зі зменшенням ступеня ризику щодо мотиваційних аспектів. Важливо зазначити, що ефективність будь-якого виду навчання на відстані залежить від чотирьох складників:

1) ефективної взаємодії викладача і студента;

2) педагогічних технологій;

3) ефективності розроблених методичних матеріалів;

4) продуктивності зворотного зв'язку.

Успішність і якість дистанційного навчання здебільшого залежать від організації та якості методичних матеріалів, які використовуються, а також від майстерності педагогів, які беруть участь у дистанційному навчанні. Незважаючи на всі негативні сторони дистанційної освіти, хочеться висловити надію на впровадження існуючих інформаційних технологій у навчальний процес 3ВО та розвиток нових технологій, більш досконалих за формою й адаптованих до українських умов.

Перспективу і вдосконалення системи дистанційного навчання в Україні має впровадження в освітній процес комп'ютерної і аудіо-візуальної техніки. Нині проблему дистанційної освіти розробляють практично всі заклади вищої освіти на території України. У перспективі електронна освіта зробить навчання не нудним і ретельно розпланованим зобов'язанням, а захоплюючим пізнавальним процесом, у формуванні якого студент сам бере участь. Вчитися всюди, завжди і все життя із задоволенням - приблизно таке гасло ідеї дистанційної освіти.

\section{СПИСОК ВИКОРИСТАНИХ ДЖЕРЕЛ}

1. Адлер А. Понять природу человека. СПб. : Гуманитарное агентство «Академический проект», 1997. 256 с.

2. Берн Э. Игры, в которые играют люди, и люди, которые играют в игры. Екатеринбург : ЛИТУР, 2001. 576 с.

3. Васюк О., Скумін Т. Теоретико-методичні аспекти організації дистанційної освіти. Вісник Книжсковӧ палати України. 2011. № 2. С. 30-32.

4. Лебон Г. Психология народов и масс. М. : Академический проект, 2011. 238 с.

5. Москаль Ю. Світові тенденції розвитку заочної та дистанційної вищої освіти. Психологія і суспільство. 2008. № 3. C. 116-122.

6. Овчарук О. В. Дистанційна освіта в європейських країнах та США в контексті розвитку інноваційних технологій. Комп'ютер у школі та сім'ї. 2004. № 7. С. 37-40. 
Романова О., Мудрик О. Психолого-педагогічні принципи створення ...

\section{REFERENCES}

1. Adler A. (1997) Ponyat prirodu cheloveka [To understand human nature]. St. Petersburg : Gumanitarnoe agentstvo "Akademicheskiy proekt" [in Russian].

2. Bern E. (2001) Igryi, v kotoryie igrayut lyudi, i lyudi, kotoryie igrayut vigryi. [Games that people play and people who play games]. Ekaterinburg : LITUR [in Russian].

3. Vasiuk O., Skumin T. (2011) Teoretyko-metodychni aspekty orhanizatsii dystantsiinoi osvity [Theoretical and methodological aspects of distance education]. Visnyk Knyzhkovoi palaty Ukrainy, № 2, p. 30-32.

4. Lebon G. (2011) Psihologiya narodov i mass [Psychology of peoples and masses]. Moskow : Akademicheskiy proekt [in Russian].

5. Moskal Yu. (2008) Svitovi tendentsii rozvytku zaochnoi ta dystantsiinoi vyshchoi osvity [World trends in the development of part-time and distance higher education]. Psykholohiia i suspilstvo, № 3, p. 116-122.

6. Ovcharuk O. V. (2004) Dystantsiina osvita v yevropeiskykh krainakh ta SShA u konteksti rozvytku innovatsiinykh tekhnolohii [Distance education in European countries and the United States in the context of the development of innovative technologies]. Kompiuter u shkoli ta simi, № 7, p. 37-40. 